\section{STUDENT WORKSHEET DESIGN (LKPD) BASED ON THINK PAIR SHARE (TPS) COOPERATIVE LEARNING MODEL JUNIOR HIGH SCHOOL STUDENTS}

\author{
Putri Maisyarah Ammy \\ Universitas Muhammadiyah Sumatera Utara \\ E-mail: putrimaisyarah@umsu.ac.id
}

\begin{abstract}
The purpose of this study was to determine the design of LKPD based on the TPS learning model for junior high school students. This research model is the ADDIE development model which consists of five stages, namely Analysis, Design, Development, Implementation, Evaluation, but in this study the researchers limited it only to the development stage. (Development). The subjects of this study were six experts consisting of two mathematics education lecturers and one mathematics teacher as a material expert as well as two mathematics education lecturers and one mathematics teacher as a media expert. While the object is LKPD based on TPS learning model. The research instrument used was a learning media questionnaire. Consists of a questionnaire of material experts and media experts. Based on data analysis, the average value obtained by material experts is 4.3 and media experts is 4.4. From these results, it can be stated that the mathematics learning media meets the validity requirements of the learning media with an overall average value of 4.3 including in the Very Good category. Thus, from the validation results it can be stated that the LKPD based on the TPS learning model meets the validity requirements and is declared eligible.
\end{abstract}

Keywords: LKPD, Learning Model, TPS

\section{INTRODUCTION}

The type of research used is research and development method or called Research and Development (R\&D). according toSugiyono (2015) R\&D is a research method used to produce certain products and test the effectiveness of these products. The procedure of this research using the ADDIE development model includes five stages, namely analysis, design, development, implementation and evaluation. However, in this study, researchers only limited it to the development stage. So, The stages in the development of this LKPD are analysis (analysis), design (design), development (development).

The data collection procedure in this study was in the form of a questionnaire. The questionnaire used is an assessment questionnaire by material experts and media experts. The grid of the questionnaire is as follows:

Table 1. Grid of Assessment Questionnaires by Material Experts

\begin{tabular}{|l|l|}
\hline $\begin{array}{l}\text { Assessment } \\
\text { Aspect }\end{array}$ & \multicolumn{1}{|c|}{ Rating Indicator } \\
\hline \multirow{4}{*}{ Format } & LKPD cover has an appeal \\
\cline { 2 - 2 } & Clear instructions for use \\
\cline { 2 - 2 } & Format compatibility as a worksheet \\
\cline { 2 - 2 } & $\begin{array}{l}\text { The suitability of the contents on the worksheet with the desired concept } \\
\text { or definition }\end{array}$ \\
\cline { 2 - 3 } & The suitability of colors, writings and images on teaching materials \\
\hline
\end{tabular}


Student Worksheet Design (LKPD) Based On Think Pair Share (TPS) Cooperative Learning Model Juinor High School Students

Putri Maisyarah

\begin{tabular}{|l|l|}
\hline \multirow{4}{*}{ The suitability of pictures and writings with questions } \\
\hline \multirow{4}{*}{ Contents } & $\begin{array}{c}\text { The suitability of the material Relations and Functions with } \\
\text { competency standards and basic competencies }\end{array}$ \\
\cline { 2 - 3 } & $\begin{array}{c}\text { The suitability of the material Relations and Functions based on the think } \\
\text { pair share cooperative learning model }\end{array}$ \\
\cline { 2 - 3 } & Conformity between the material Relations and Functions with LKPD \\
\cline { 2 - 3 } & $\begin{array}{c}\text { Clarity of the concept of Relation and Function material is submitted to } \\
\text { the LKPD }\end{array}$ \\
\cline { 2 - 3 } & Examples that are suitable for everyday life \\
\cline { 2 - 3 } & Pictures, diagrams and illustrations in everyday life \\
\cline { 2 - 3 } & Clarity of the example questions given \\
\cline { 2 - 3 } & Order of presentation of material \\
\cline { 2 - 3 } & $\begin{array}{c}\text { The suitability of the order of learning materials with the level of ability } \\
\text { of students }\end{array}$ \\
\hline Aanguage & Appropriate use of the word EYD \\
\cline { 2 - 3 } & Ease of understanding the language used \\
\cline { 2 - 3 } & Ease of use of sentences \\
\cline { 2 - 3 } & Complete sentences of information needed by students \\
\cline { 2 - 3 } & Simplicity of sentence structure \\
\hline
\end{tabular}

Table 2 Grid of Assessment Questionnaires by Media Experts

\begin{tabular}{|c|c|}
\hline $\begin{array}{l}\text { Assessment } \\
\text { Aspect }\end{array}$ & Rating Indicator \\
\hline \multirow[b]{2}{*}{ Coloring } & The color combination on the worksheet is interesting \\
\hline & $\begin{array}{l}\text { The suitability of the presentation of the images and the material } \\
\text { discussed }\end{array}$ \\
\hline \multirow{4}{*}{$\begin{array}{l}\text { Use of } \\
\text { Words and } \\
\text { Language }\end{array}$} & Using Indonesian in accordance with Enhanced Spelling (EYD) \\
\hline & The language used in LKPD is easy for students to understand \\
\hline & Politeness of using language \\
\hline & Dialogue/Text accuracy with story/material \\
\hline \multirow[t]{3}{*}{$\begin{array}{l}\text { LKPD } \\
\text { Display }\end{array}$} & $\begin{array}{l}\text { The image design gives a positive impression so that it can attract } \\
\text { interest in learning }\end{array}$ \\
\hline & The type of font used is clear and legible \\
\hline & LKPD cover has an appeal \\
\hline \multirow[t]{3}{*}{ Presentation } & LKPD presentation supports students to look active in learning \\
\hline & LKPD presentation is carried out in a coherent manner \\
\hline & LKPD steps are easy to understand \\
\hline
\end{tabular}

according to Eko Putro Widoyoko, S. (2009), converts the average score obtained into a 5-scale conversion table into a qualitative value or LKPD quality assessment criteria are as follows: 
Table 3. LKPD Quality Assessment Criteria

\begin{tabular}{|c|c|c|}
\hline Formula & Score & Category \\
\hline $\bar{x}>M i+1,8 S b i$ & 5 & Very good \\
\hline$M i+0,8 S b i<\bar{x} \leq M i$ & 4 & Well \\
$+1,8 S b i$ & & \\
\hline$M i-0,8 S b i<\bar{x} \leq M i+0,8 S b i$ & 3 & Enough \\
\hline$M i-1,8 S b i<\bar{x} \leq M i-0,8 S b i$ & 2 & Not enough \\
\hline$X \leq M i-1,8 S b i$ & 1 & Very less \\
\hline
\end{tabular}

Information :

$M i=$ rata - rata ideal $=1 / 2$ (skor terting gi ideal + skor terendah ideal $)$

$S b i=$ simpangan baku $=1 / 6$ (skor maksimal ideal - skor minimal ideal $)$

$\bar{x}=$ actual score

\section{IMPLEMENTATION METHOD}

The type of research used is research and development method or called Research and Development (R\&D). according toSugiyono (2015)R\&D is a research method used to produce certain products and test the effectiveness of these products. The procedure of this research using the ADDIE development model includes five stages, namely analysis, design, development, implementation and evaluation. However, in this study, researchers only limited it to the development stage. So, The stages in the development of this LKPD are analysis (analysis), design (design), development (development).

The data collection procedure in this study was in the form of a questionnaire. The questionnaire used is an assessment questionnaire by material experts and media experts. The grid of the questionnaire is as follows:

Table 1. Grid of Assessment Questionnaires by Material Experts

\begin{tabular}{|c|c|}
\hline $\begin{array}{l}\text { Assessment } \\
\text { Aspect }\end{array}$ & Rating Indicator \\
\hline \multirow{6}{*}{ Format } & LKPD cover has an appeal \\
\hline & Clear instructions for use \\
\hline & Format compatibility as a worksheet \\
\hline & $\begin{array}{l}\text { The suitability of the contents on the worksheet with the desired concept } \\
\text { or definition }\end{array}$ \\
\hline & The suitability of colors, writings and images on teaching materials \\
\hline & The suitability of pictures and writings with questions \\
\hline \multirow{5}{*}{ Contents } & $\begin{array}{l}\text { The suitability of the material Relations and Functions with } \\
\text { competency standards and basic competencies }\end{array}$ \\
\hline & $\begin{array}{l}\text { The suitability of the material Relations and Functions based on the think } \\
\text { pair share cooperative learning model }\end{array}$ \\
\hline & Conformity between the material Relations and Functions with LKPD \\
\hline & $\begin{array}{l}\text { Clarity of the concept of Relation and Function material is submitted to } \\
\text { the LKPD }\end{array}$ \\
\hline & Examples that are suitable for everyday life \\
\hline
\end{tabular}


Student Worksheet Design (LKPD) Based On Think Pair Share (TPS) Cooperative Learning Model Juinor High School Students

Putri Maisyarah

\begin{tabular}{|l|l|}
\hline \multirow{4}{*}{} & Clarity of the example questions given \\
\cline { 2 - 3 } & Order of presentation of material \\
& $\begin{array}{c}\text { The suitability of the order of learning materials with the level of ability } \\
\text { of students }\end{array}$ \\
\hline Language & Appropriate use of the word EYD \\
\cline { 2 - 3 } & Ease of understanding the language used \\
\cline { 2 - 2 } & Ease of use of sentences \\
\cline { 2 - 3 } & Complete sentences of information needed by students \\
\cline { 2 - 2 } & Simplicity of sentence structure \\
\hline
\end{tabular}

Table 2 Grid of Assessment Questionnaires by Media Experts

\begin{tabular}{|l|l|}
\hline $\begin{array}{l}\text { Assessment } \\
\text { Aspect }\end{array}$ & \multicolumn{1}{|c}{ Rating Indicator } \\
\hline \multirow{2}{*}{ Coloring } & The color combination on the worksheet is interesting \\
\cline { 2 - 2 } \begin{tabular}{l} 
Use of $\begin{array}{l}\text { Words and } \\
\text { Language }\end{array}$ \\
\cline { 2 - 2 }
\end{tabular} & The suitability of the presentation of the images and the material discussed \\
\cline { 2 - 2 } & The Indonesian in accordance with Enhanced Spelling (EYD) \\
\cline { 2 - 2 } $\begin{array}{l}\text { LKPD } \\
\text { Display }\end{array}$ & Politeness of using language \\
\cline { 2 - 2 } & Dialogue/Text accuracy with story/material \\
\cline { 2 - 2 } & The image design gives a positive impression so that it can attract interest \\
\hline Presentation & The type of font used is clear and legible \\
\cline { 2 - 2 } & LKPD cover has an appeal \\
\cline { 2 - 2 } & LKPD presentation supports students to look active in learning \\
\cline { 2 - 2 } & LKPD steps are easy to understand \\
\hline
\end{tabular}

according to Eko Putro Widoyoko, S. (2009), converts the average score obtained into a 5-scale conversion table into a qualitative value or LKPD quality assessment criteria are as follows:

Table 3. LKPD Quality Assessment Criteria

\begin{tabular}{|c|c|c|}
\hline Formula & Score & Category \\
\hline $\bar{x}>M i+1,8 S b i$ & 5 & Very good \\
\hline$M i+0,8 S b i<\bar{x} \leq M i+1,8 S b i$ & 4 & Well \\
\hline$M i-0,8 S b i<\bar{x} \leq M i+0,8 S b i$ & 3 & Enough \\
\hline$M i-1,8 S b i<\bar{x} \leq M i-0,8 S b i$ & 2 & Not enough \\
\hline$X \leq M i-1,8 S b i$ & 1 & Very less \\
\hline
\end{tabular}

Information :

$M i=$ rata - rata ideal $=1 / 2$ (skor tertinggi ideal + skor terendah ideal)

$S b i=$ simpangan baku $=1 / 6$ (skor maksimal ideal - skor minimal ideal)

$\bar{x}=$ actual score

\section{RESULTS AND DISCUSSION}

In this study, researchers produced a learning media product in the form of LKPD. The research procedures carried out are: 


\section{ORFAI JOURNAL Multidiciplinary Output Research For Actual and International Issue}

a. The Analysis stage is the most important stage in this research. At this stage, the researcher analyzes the curriculum, the needs of students and analyzes the concept ofLKPDwhich will be developed later. This LKPD was developed in accordance with the 2013 curriculum on the subject of relations and functions for class VIII SMP.

b. In the Design phase, the researcher makes a design or design for theLKPDdeveloped. The stages of this design are collecting references, preparing materials, examples and questions, and making the LKPD design.

c. The Development Phase is carried out to make conceptual designs produced in the previous stage realized into products that are ready to be implemented in real situations (classes) (Endang Mulyatiningsih, 2011: 185). The stages are (1) product design development which includes cover, introduction, table of contents, concept map, basic competence, indicators, learning objectives, instructions for using LKPD, summary of material, sample questions, and practice questions; (2) Validation which includes material experts and medical experts, each of which consists of 2 mathematics lecturers and 1 mathematics teacher; (3) Revisions which include any matters suggested or revised by material experts and media experts.

In general, the differences between existing LKPDs in schools and LKPDs that have been developed can be seen in the image below:

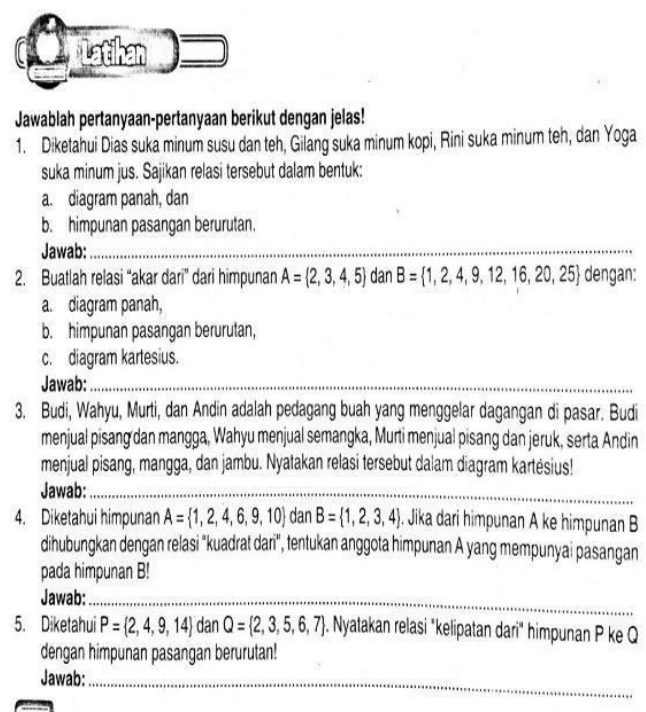

Figure 1. LKPD before Development
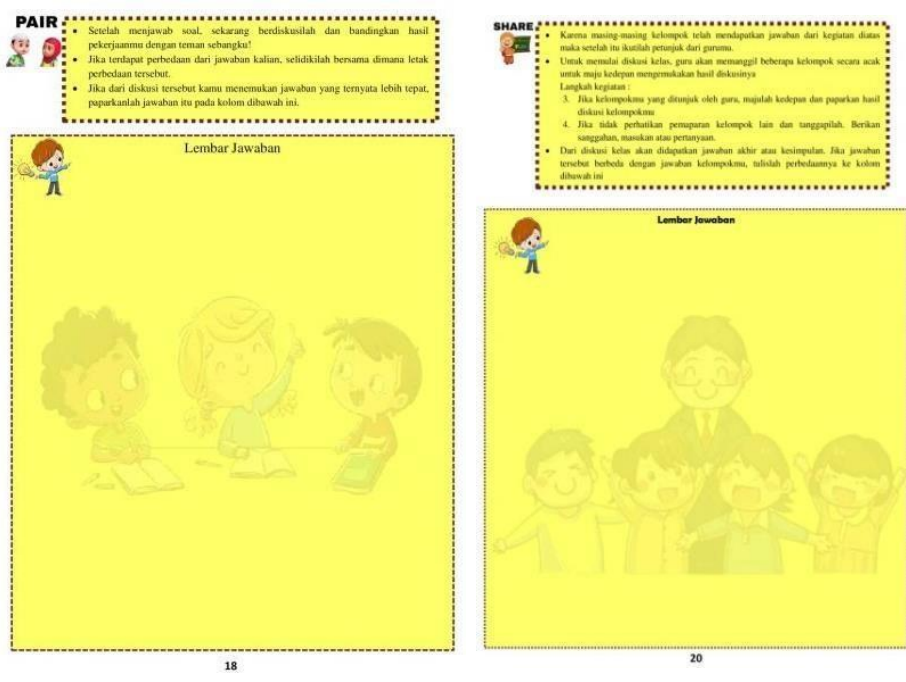

Figure 2. LKPD after Development

From the picture above, it can be seen that the LKPD before the development used the presentation of questions without instructions for working on the questions, while the LKPD that had been developed had a flow of questions. The following is a display of the developed LKPD products:
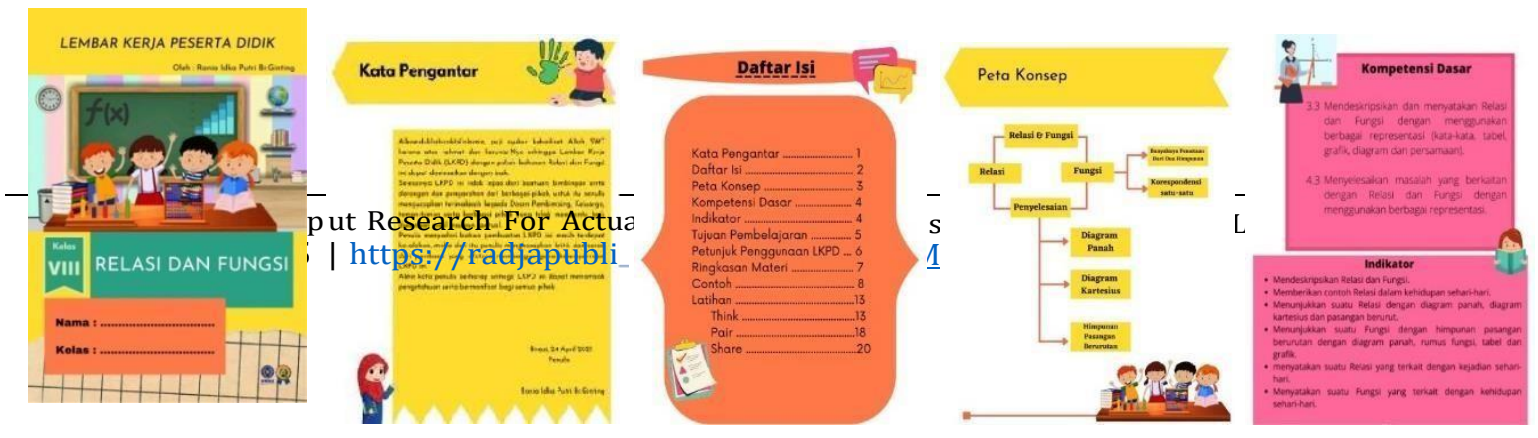
Student Worksheet Design (LKPD) Based On Think Pair Share (TPS) Cooperative Learning Model Juinor High School Students

Putri Maisyarah

Cover

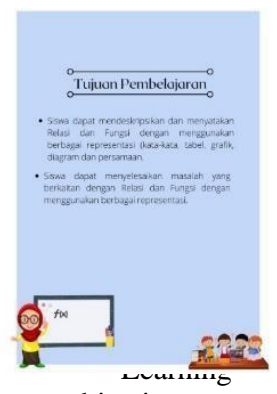

objectives
Foreword

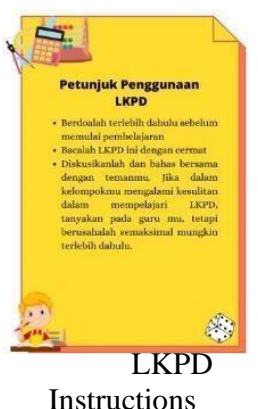

list of

contents

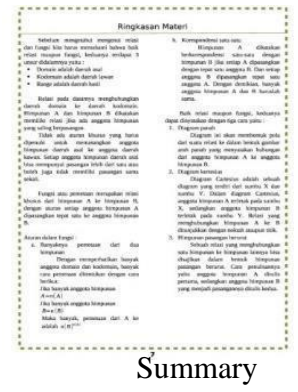

Concept

maps

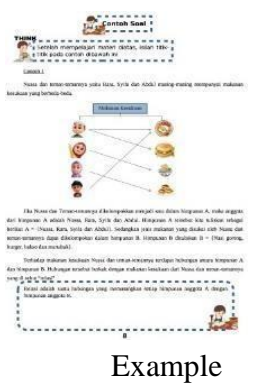

$\mathrm{KD}$ and

Indicator

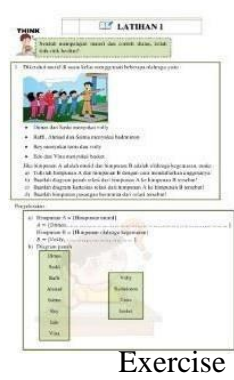

After the LKPD has been developed, then do validation to find out the validity of the developed LKPD. This validation is carried out by material experts and media experts, whereeach expert consists of 2 mathematics lecturers and 1 mathematics teacher. The results of the validation by material experts and media experts can be seen in the table below:

Table 4. Material Expert Validation Results

\begin{tabular}{|c|c|c|c|c|c|c|}
\hline \multirow[b]{2}{*}{ No } & \multirow{2}{*}{$\begin{array}{l}\text { Assessme } \\
\text { nt Aspect }\end{array}$} & \multicolumn{3}{|c|}{ Total Score } & \multirow{2}{*}{$\begin{array}{l}\text { Average } \\
\text { Score }\end{array}$} & \multirow[b]{2}{*}{ Criteria } \\
\hline & & 1 & 2 & 3 & & \\
\hline 1 & Format & & & .5 & 4.1 & Good (B) \\
\hline 2 & Contents & & & .9 & 4.3 & $\begin{array}{r}\text { Very } \\
\text { Good (SB) }\end{array}$ \\
\hline 3 & Language & & .6 & .8 & 4.5 & $\begin{array}{r}\text { Very } \\
\text { Good (SB) }\end{array}$ \\
\hline \multicolumn{5}{|c|}{ Total Average Score } & 4.3 & $\begin{array}{r}\text { Very } \\
\text { Good (SB) }\end{array}$ \\
\hline
\end{tabular}

Table 5. Media Expert Validation Results

\begin{tabular}{|c|l|c|c|c|c|c|}
\hline \multirow{2}{*}{ No } & \multirow{2}{*}{$\begin{array}{l}\text { Assessment } \\
\text { Aspect }\end{array}$} & $\mathbf{1}$ & $\mathbf{2}$ & $\mathbf{3}$ & $\begin{array}{c}|c| \\
\text { Trage } \\
\text { Score }\end{array}$ & Criteria \\
\cline { 2 - 6 } & \multicolumn{1}{|c|}{ Coloring } & .5 & .0 & .5 & 4.0 & Good (B) \\
\hline 2 & $\begin{array}{l}\text { Use of Words } \\
\text { and Language }\end{array}$ & .5 & .5 & .7 & 4.6 & $\begin{array}{c}\text { Very } \\
\text { Good (B) }\end{array}$ \\
\hline 3 & LKPD Display & .7 & .3 & .0 & 4.3 & $\begin{array}{c}\text { Very } \\
\text { Good (SB) }\end{array}$ \\
\hline 4 & Presentation & .6 & .0 & .3 & 4.6 & $\begin{array}{c}\text { Very } \\
\text { Good (SB) }\end{array}$ \\
\hline
\end{tabular}


Based on the results of the LKPD validation carried out by material experts, the average value of the three material experts for the format aspect is 4.1 , the content aspect is 4.3, and the language aspect is 4.5. From the assessments of three material experts, the average value of the three aspects was 4.3. While the results of the LKPD validation carried out by media experts obtained the average value for the coloring aspect of 4.0 , the word and language use aspect of 4.6, the LKPD display aspect of 4.3 and the presentation aspect of 4.6. So that the assessment of these three media experts obtained an average value of 4.4. Based on the assessment by material experts who obtained an average value of 4.3 and the average value by media experts of 4.4 then using a score range of 1 to 5 the average value assessed by material experts and media experts was included in the criteria "Very good". Thus, from the validation results, it can be stated that the LKPD developed meets the validity requirements and is declared eligible and can be used to assist students in the learning process.

\section{CONCLUSION}

This LKPD was developed using the ADDIE research procedure which consists of five main stages, namely (analysis, design, development, implementation, evaluation). However, in this study the researchers only limited it to the development stage. So the development stage in this research is the analysis, design and development stages. The assessment of the level of validity of the material on the LKPD was assessed by three material expert validators consisting of two mathematics education lecturers and one mathematics teacher. The assessment obtained an average score of 4.3 with the criteria of "Very Good". As for the media validity assessment carried out by three media experts consisting of two mathematics education lecturers and one mathematics teacher, the average score was 4.4 with the criteria of "Very Good". From the results of the assessment carried out by material experts and media experts, it was concluded that the LKPD developed met the validity requirements with an overall average score of 4.3 with the criteria of "Very Good".

\section{REFERENCES}

Andi Prastowo. (2015). Panduan Kreatif Membuat Bahan Ajar Inovatif. Yogyakarta: Diva Press (2014). Paradigma Baru Madrasah Dalam Implementasi Kebijakan

Kurikulum 2013. Jurnal Pendidikan Islam, 3(1), 95-113.

Depdiknas. (2008). Peraturan Pemerintah RI No.19 Tahun 2005 tentang Standar Nasional Pendidikan. Jakarta:

Eko Putro Widoyoko, S. (2009). Evaluasi Program Pembelajaran. Yogyakarta: Pustaka Pelajar. Hamdani. (2013). Strategi Belajar Mengajar. Bandung: CV Pustaka Setia.

Hidayat, A. A. A. (2011). Metode Penelitian Keperawatan Dan Teknik Analisis Data. Jakarta: Salemba Medika. 
Student Worksheet Design (LKPD) Based On Think Pair Share (TPS) Cooperative Learning Model Juinor High School Students

Putri Maisyarah

Mulyatiningsih, E., \& Nuryanto, A. (2014). Metode penelitian terapan bidang pendidikan. Yogyakarta: Alfabeta.

Permendikbud Republik Indonesia Nomor 54. (2013). Tentang Standar Kompetensi Lulusan (SKL).

Sugiyono, D. (2013). Metode Penelitian Pendidikan Pendekatan Kuantitatif, Kualitatif Dan R\&D.

Umbaryati, U. (2016, February). Pentingnya LKPD pada Pendekatan Scientific Pembelajaran Matematika. In PRISMA, Prosiding Seminar Nasional Matematika (pp. 217-225). 